\title{
Effect of adding cysteine to brain-heart infusion broth on the isolation of Bacteroides fragilis from experimental blood cultures
}

\author{
DC SHANSON AND J SINGH \\ From the Department of Clinical Microbiology, St Stephen's Hospital, Fulham Road, London SW10 9TH, UK
}

SUMMARY Adding $0.05 \%$ cysteine to brain-heart infusion broth greatly improved the recovery of three strains of Bacteroides fragilis from simulated blood cultures. No bacteroides were isolated after 24 hours' incubation in brain-heart infusion broth without added cysteine, and this was therefore a poor medium for the isolation of $B$. fragilis. Results with brain-heart infusion broth containing $0.05 \%$ cysteine were similar to those obtained with commercially prepared Thiol and Brewer's thioglycollate media.

The choice of anaerobic medium is critical for the successful isolation of Bacteroides fragilis from the blood. There have been several reports on anaerobic blood culture media in recent years based on the results of simulated blood culture experiments. Thioglycollate media were superior to cooked-meat media for the early growth of bacteroides. ${ }^{12}$ In a series of experiments in 1973 with media in common use Brewer's thioglycollate (Southern Group Laboratories) $80 \mathrm{ml}$ gave the best overall results. ${ }^{1}$ This medium was recommended in the Association of Clinical Pathologists Broadsheet on blood culture techniques. ${ }^{3}$ There was little difference between Brewer's thioglycollate medium and Thiol medium $50 \mathrm{ml}$ under vacuum with added carbon dioxide for isolating $B$. fragilis, ${ }^{4}$ but in a subsequent study Thiol gave better results than thioglycollate media. ${ }^{5}$ Recently, Collee et al. ${ }^{6}$ reported that Thiol medium was inferior to Brewer's thioglycollate medium for isolating bacteroides. Their best results were with a mixture of brain-heart infusion broth and cookedmeat broth. They found brain-heart infusion broth without added cooked meat a poor medium for isolating $B$. fragilis.

The purpose of the present study was to investigate the effect on the isolation of $B$. fragilis from simulated blood cultures of adding cysteine, a known reducing substance, to brain-heart infusion broth reconstituted from a commercial dehydrated powder. We also compared it with Brewer's thioglycollate medium (Southern Group Laboratories) and Thiol

Accepted for publication 2 July 1980 medium under vacuum with added carbon dioxide (Difco).

\section{Material and methods}

BLOOD CULTURE MEDIA

(1) Brain-heart infusion broth (Bacto 0037-01, control 657821, Difco) prepared by dissolving $37 \mathrm{~g}$ powder in $500 \mathrm{ml}$ distilled water, adjusting the $\mathrm{pH}$ to $7 \cdot 4$, and making up to 11 . The broth was dispensed in $50-\mathrm{ml}$ volumes and autoclaved at $121^{\circ} \mathrm{C}$ for 15 minutes.

(2) Brain-heart infusion broth (Difco) with cysteine $0.05 \%$. This was prepared in a similar way to (1) but with the addition of L-cysteine (BDH Chemicals Ltd). L-Cysteine $0.5 \mathrm{~g}$ was dissolved in $5 \mathrm{ml}$ normal hydrochloric acid and the $5 \mathrm{ml}$ solution added to $500 \mathrm{ml}$ broth, $\mathrm{pH}$ adjusted to $7 \cdot 4$, and made up to 11 with more broth. The brain-heart infusion broth containing cysteine was dispensed in $50-\mathrm{ml}$ volumes and autoclaved at $121^{\circ} \mathrm{C}$ for 15 minutes.

(3) Thiol broth (Difco, 0355-37-8) $50 \mathrm{ml}$ under vacuum and with carbon dioxide prepared by the manufacturers.

(4) Brewer's thioglycollate $80 \mathrm{ml}$ (Southern Group Laboratories, 0586C).

\section{BLOOD}

Defibrinated horse blood $5 \mathrm{ml}$ (Tissue Culture Services) added to each broth just before the bacteroides were added. 
BACTERIA

Three strains of $B$. fragilis freshly isolated on blood agar from the wound swabs of different patients with abdominal sepsis.

\section{INOCULATION}

The inoculum was calculated by making viable counts of dilutions of 48-hour cooked-meat cultures of the strains to be tested by the Miles and Misra method. After preliminary tests $0.25 \mathrm{ml}$ of the dilution likely to contain the required number of viable organisms was inoculated into the test bloodbroths by puncturing each cap with a separate needle attached to a disposable 1-ml syringe. The actual inoculum was checked on each occasion by concurrent viable counts of the dilution inoculated using blood agar incubated in anaerobic jars containing $10 \%$ carbon dioxide. Colonies were counted after 48 hours' incubation.

\section{METHOD FOR EACH EXPERIMENT}

Each medium was tested either in duplicate or in triplicate. After inoculation the bottles were incubated without the use of an anaerobic jar at $35^{\circ} \mathrm{C}$. Bottles were subcultured on to blood agar after one, two, and five days' incubation using syringes and needles for the subcultures. The blood-agar plates were incubated in anaerobic jars containing $10 \%$ carbon dioxide for up to 48 hours.

\section{Results}

The addition of cysteine $0.05 \%$ to the brain-heart infusion broth enormously improved the recovery of the $B$. fragilis strains from the blood broths even after only 24 hours' incubation (Table). No bacteroides were isolated from the brain-heart infusion broth without added cysteine after two days' incubation but after five days' incubation $B$. fragilis was isolated from 11 of the 21 bottles. There were the same number of bacteroides isolations after two and five days' incubation from the brain-heart infusion broths containing $0.05 \%$ cysteine as there were after 24 hours' incubation.

The brain-heart infusion broth with $0.05 \%$ cysteine, the Thiol, and the Brewer's thioglycollate media all yielded growth of bacteroides from 19 out of 21 bottles after 24 hours', 48 hours', and 5 days' incubation.

\section{Discussion}

Brain-heart infusion broth without additives was a poor medium for the isolation of $B$. fragilis. This confirms the observation of Collee et al. ${ }^{6}$ However, the simple addition of $0.05 \%$ cysteine to the brainheart infusion broth greatly improved the isolation of the bacteroides strains from the broth after only 24 hours' incubation of the simulated blood cultures. Laboratories that rely on brain-heart infusion broth for the isolation of $\boldsymbol{B}$. fragilis from blood cultures should consider the routine addition of cysteine to the medium.

Interestingly, the results obtained with the brainheart infusion broth containing $0.05 \%$ cysteine were identical with those obtained with the much more expensive Thiol medium under vacuum with added carbon dioxide and the Brewer's thioglycollate medium.

\section{References}

${ }^{1}$ Shanson DC. An experimental assessment of different anaerobic blood culture methods. J Clin Pathol 1974 27:273-9.

${ }^{2}$ Forgan-Smith WR, Darrell JH. A comparison of media used in vitro to isolate non-sporing Gram-negative anaerobes from blood. J Clin Pathol 1974;27:280-3.

${ }^{3}$ Stokes EJ. Blood culture technique. Association of Clinical Pathologists Broadsheet 81;1974.

- Shanson DC, Barnicoat M. An experimental comparison of Thiol broth with Brewer's thioglycollate for anaerobic blood cultures. J Clin Pathol 1975;28:407-9.

- Szawatowski MV. A comparison of three readily available types of anaerobic blood culture media. Med Lab Sci

Results of subculture of brain-heart infusion (BHI) blood broths after 24 hours' incubation

\begin{tabular}{|c|c|c|c|c|c|c|}
\hline \multirow{2}{*}{$\begin{array}{l}\text { Culture } \\
\text { No. }\end{array}$} & \multirow[t]{2}{*}{ Organism } & \multirow[t]{2}{*}{ Inoculum* } & \multicolumn{2}{|l|}{ BHI and cysteine $0.05 \%$} & \multicolumn{2}{|l|}{$\boldsymbol{B H I}$} \\
\hline & & & No. bottles inoculated & No. bottles positive & No. bottles inoculated & No. bottles positive \\
\hline & & Totals & 21 & 19 & 21 & 0 \\
\hline
\end{tabular}

*Viable particles added per bottle. 
1976;33:5-12.

- Collee JG, Duerden BI, Brown R. Recovery of anaerobic bacteria from small inocula: a model for blood culture studies. J Clin Pathol 1977;30:609-14.
Requests for reprints to: Dr DC Shanson, Division of Pathology, St Stephen's Hospital, Chelsea, London SW10 9TH.

\section{Reports and Bulletins prepared by the Association of Clinical Biochemists}

The following reports and bulletins are published by the Association of Clinical Biochemists. They may be obtained from The Publishing Department, British Medical Journal (ACB Technical Bulletins), BMA House, Tavistock Square, London WC1H 9JR. Overseas readers should remit by British Postal or Money Order.

SCIENTIFIC REVIEWS (price $£ 1 \cdot 00 / \$ 2.00$ each)

1 The assessment of thyroid function March 1971 FV FLYNN and JR HOBBS

2 Renal function tests suitable for clinical practice January 1972 FL MTCHELL, N VEALL, and RWE WATTS

3 Biochemical tests for the assessment of fetoplacental function May 1975 CE WILDE and RE OAKEY

4 Test of exocrine pancreatic function March 1977 AH GOWENLOCK

5 Assay of cholinesterase in clinical chemistry 1979 ELSIE SILK, J KING, and MARY WHITTAKER

March

TECHNICAL BULLETINS (price $£ 1 \cdot 00 / \$ 2.00$ each)

22 Bilirubin standards and the determination of bilirubin by manual and technicon AutoAnalyzer methods January 1971 BARBARA BILLING, RUTH HASLAM, and N WALD

23 Interchangeable cells for spectrophotometers and fluorimeters September 1971 ss BROWN and AH GOWENLOCK

24 Simple tests to detect poisons March 1972 BW MEADE et al.

25 Blood gas analysers May 1972 K DIXON

26 Kits for enzyme activity determination September 1972 SB ROSALKI and D TARLOW

27 Assessment of pumps suitable for incorporation into existing continuous flow analytical systems November 1972 A FLECK et al.

28 Routine clinical measurements of transferrin in human serum September 1973 K DIXON
29 Control materials for clinical biochemistry (5th edition) September 1973 JF STEVENS

30 Notes on the quality of performance of serum cholesterol assays September 1973 sS BROWN

31 Determination of uric acid in blood and in urine July 1974 RWE WATTS

32 A survey of amino acid analysers readily available in the United Kingdom September 1974 JE CARLYLE and P PURKISS

33 Definitions of some words and terms used in automated analysis November 1974 A FLECK, R ROBINSON, SS BROWN, and JR HOBBS

34 Measurement of albumin in the sera of patients January 1975 LINDA SLATER, PM CARTER, and JR HOBBS

35 Investigation of the validity of temperature correction factors for serum aspartate and alanine transaminases March 1975 SB ROSALKI et al.

36 Factors influencing the assay of creatinine November 1975 JGH COOK

37 A survey of enzyme reaction rate analysers readily available in the United Kingdom July 1977 RA SAUNDERS and RF BURNS

38 Transport of specimens for clinical chemistry analysis November 1977 P WILDING, JF ZILVA, and CE WILDE

39 A scheme for the evaluation of diagnostic kits May 1978 PH LLOYD

40 A practical guide to gamma-counting in radioimmunoassay January 1980 CE WILDE and D OTTEWELL

41 The use of biochemical tests in the diagnosis of disorders of calcium metabolism July 1980 ANGELA FAIRNEY 